\title{
Pembangunan Pariwisata Berkelanjutan: Studi tentang Pengembangan Wisata Gua Selomangleng di Kota Kediri
}

\author{
Heylen Amildha Yanuarita \\ Program Studi Ilmu Administrasi Negara, Fakultas Ilmu Sosial dan Ilmu Politik. \\ Universitas Kediri \\ Kediri, Indonesia 64112 \\ Email : Heylen.Amildha@gmail.com
}

\begin{abstract}
This article aims to determine the extent of the development of Selomangleng Cave in the City of Kediri in the perspective of sustainable tourism development. In this study the researcher used a qualitative descriptive method in which the researcher elaborated, described, explained, concerning matters related to the development of Selomangleng Cave tourism objects, as well as the development implications, challenges ahead in the perspective of sustainable development. The results of this study concluded that the development of the Selomangleng Cave of the City of Kediri was still very minimal, constrained by the issue of land ownership, however there was still an effort to develop Selomangleng Cave tourism in accordance with the principles of sustainable development.
\end{abstract}

Keywords: Sustainable development; tourism; local tourism

\begin{abstract}
Abstrak
Artikel ini bertujuan untuk mengetahui sejauh mana pengembangan Gua Selomangleng di Kota Kediri dalam perspektif pembangunan pariwisata berkelanjutan. Dalam penelitian ini Peneliti menggunakan metode deskriptif kualitatif dimana peneliti menguraikan, menggambarkan, menjelaskan, mengenai hal-hal yang terkait dengan pengembangan obyek pariwisata Gua Selomangleng, serta implikasi pengembangan, tantangan kedepan dalam perspektif pembangunan berkelanjutan. Hasil penelitian ini menyimpulkan bahwa pengembangan wisata Gua Selomangleng Kota Kediri masih sangat minim, terkendala dengan persoalan kepemilikan lahan, namun demikian tetap ada usaha pengembangan wisata Gua Selomangleng yang sesuai dengan prinsip pembangunan berkelanjutan.
\end{abstract}

Kata kunci: Pembangunan berkelanjutan; wisata; pariwisata lokal

Link DOI : $\underline{\text { http://dx.doi.org/10.31314/pjia.7.2.136-146.2018 }}$

Copyright @ 2018, Publik : (Jurnal Ilmu Administrasi), ISSN: 2301-573X (Print), ISSN: 25812084 (Online) 


\section{PENDAHULUAN}

Pertumbuhan jumlah penduduk yang sangat padat dan ketersediaan wilayah yang sangat luas, memberikan nilai positif bagi negara Indonesia yaitu menjadikan negara yang memiliki potensi sumber daya yang sangat besar, khususnya dibidang pariwisata. Hal tersebut terlihat dari indahnya berbagai macam pemandangan alam di seluruh wilayah Indonesia, banyaknya jenis kebudayaan yang ada, banyaknya peninggalan sejarah budaya bangsa, tradisi-tradisi unik yang dimiliki oleh setiap daerah di Indonesia, sebagaimana yang ada di Kota Kediri dalam hal ini wisata Gua Selomangleng. Sesuai Undang-undang nomor 10 tahun 2009 tentang Kepariwisataan, secara garis besar menjelaskan tentang hak dan kewajiban masyarakat, Wisatawan, pelaku usaha dan Pemerintah.

Selanjutnya dikatakan bahwa di dalam pembangunan kepariwisataan yang komprehensif dan berkelanjutan, perlu adanya koordinasi lintas sektor, pengaturan kawasan strategis, pemberdayaan usaha mikro, kecil dan menengah di dalam maupun di sekitar destinasi pariwisata. Disamping hal di atas, di setiap daerah yang memiliki obyek pariwisata perlu pula dibentuk Badan Promosi Pariwisata, Asosiasi Kepariwisataan, standarisasi jenis usaha dan kompetensi pekerja pariwisata serta pemberdayaan pekerja pariwisata melalui pelatihan atau training. Hak dan kewajiban tersebut di atas perlu di optimalkan oleh setiap daerah melalui penyelenggaraan pembangunan kepariwisataan yang berkelanjutan. Dengan demikian hal tersebut diharapkan dapat memperluas dan memeratakan kesempatan masyarakat untuk berwirausaha dan sekaligus membuka atau memperluas lapangan kerja baru yang akhirnya dapat meningkatkan pendapatan masyarakat, daerah dan negara. Selain itu kepariwisataan juga andil memberikan pengaruh besar terhadap pemasukan daerah maupun negara sehingga dampak yang dirasakan Pemerintah Daerah akan cepat mengalami perubahan. Oleh sebab itu pembangunan akan dapat cepat meningkat apabila potensi pariwisata di daerah juga terus berkembang secara berkelanjutan disamping sector lain.

Konsep pembangunan berkelanjutan tentu tidak akan terlepas dari konsep pembangunan itu sendiri. Hal ini karena menurut paradigm pembangunan berkelanjutan didasari perjalanan pelaksanaan pembangunan yang semakin tidak terkontrol dalams ebuah negara.

Menurut (Hadi,

pembangunan memiliki makna ganda:

1. Pembangunan yang lebih menekankan pada pertumbuhan ekonomi lebih memfokuskan pada jumlah (kuantitas) produksi dan penggunaan sumber-sumber yang ada.

2. Pembangunan yang menekankan pada perubahan disrtibusi barangbarang esensi hubungan sosial.

Adapun pembangunan berkelanjutan disamping didasari oleh perjalanan pelaksanaan pembangunan yang semakin tidak terkontrol, juga sebagai upaya pemanfaatan pembangunan yang berlansung secara berkesinambungan dengan wawasan kelestarian budaya serta berbasiskan kepentingan masyarakat. Sedang menurut 
WCED (World Commissionon on Environment and Development) dalam Hadi (2012) definisi pembangunan berkelanjutan adalah merupakan pembangunan yang diorientasikan untuk memenuhi kebutuhan masyarakat masa sekarang dan masa akan dating serta untuk melestarikan pembangunan yang sudah ada agar terus berkembang dan terkonsep dengan baik.

Pembangunan berkelanjutan memiliki prinsip-prinsip yang harus dipenuhi demi terlaksananya pembangunan dengan baik dan terarah. Menurut Baequni (2002) pembangunan berkelanjutan berkaitan dengan 4 hal, yaitu:

1. Upaya memenuhi kebutuhan manusia yang ditopang dengan kemampuan dan daya dukung ekosistem.

2. Upaya meningkatkan pemenuhan kebutuhan manusia dengan cara melindungi dan melestarikan sumber daya alam yang sudah ada dengan berkelanjutan.

3. Upaya meningkatkan sumber daya manusia dan alam yang dibutuhkan pada masa sekarang dan masa akan datang.
4. Upaya
mempertemukan
kebutuhan manusia antar generasi.

Merujuk pada Undang-undang nomor 10 tahun 2009 tentang Kepariwisataan, yang dimaksud kepariwisataan adalah seluruh kegiatan yang terkait dengan pariwisata yang muncul sebagai wujud kebutuhan setiap orang dan negara serta interaksi antar wisatawan dan masyarakat setempat, sesame wisatawan, pemerintah dan pengusaha (pedagang). Sedang yang terkait dengan sumberdaya manusia dalam hal ini pariwisata adalah berbagai macam kegiatan manusia di dukung berbagai fasilitas serta layanan yang disediakan masyarakat, pengusaha maupun pemerintah. Sebuah pariwisata tentu tidak dapat terlepas dengan industry pariwisata karena adanya industry pariwisata maka akan menjadi pelengkap untuk memenuhi segala kebutuhan wisatawan. Pembangunan pariwisata berkelanjutan pada dasarnya merupakan bagian dari konsep pembangunan berkelanjutan dengan memperhatikan prinsip-prinsip pembangunan yang mencakup ekologi, sosial-budaya dan ekonomi. Seiring dengan berjalannya waktu konsep pembangunan berkelanjutan di adopsi dengan pembangunan pariwisata berkelanjutan. Menurut Varoci dalam Yoeti (2008) menyebutkan bahwa pembangunan pariwisata berkelanjutan harus meliputi tiga hal, yaitu: Comprehensive Approach, Integrated Approach, dan Strategic Approach.

Selanjutnya indikator yang dikembangkan oleh Pemerintah Republik Indonesia tentang pembangunan pariwisata berkelanjutan adalah sebagai berikut:

1. Kesadaran tentang tanggung jawab terhadap lingkungan, bahwa strategi pembangunan pariwisata berkelanjutan harus menempatkan pariwisata di berbagai green industry yang menjadi tanggung jawab Pemerintah, industry pariwisata, masyarakat dan wisatawan.

2. Peningkatan peran Pemerintah Daerah dalam pembangunan pariwisata.

3. Kemantapan atau keberdayaan industry pariwisata harus mampu menciptakan produk-produk pariwisata 
internasional yang bisa bersaing secara internasiona masyarakat di tempat tujuan wisata.

4. Penciptaan kemitraan dan partisipasi masyarakat dalam pembangunan pariwisata yang bertujuan menghapus atau meminimalisir perbedaan tingkat kesejahteraan wisatawan dan masyarakat di daerah tujuan wisata untuk menghindari konflik dan dominasi satu sama lain.

Selanjutnya menurut Suweda (2011) dalam pelaksanaan pembangunan berkelanjutan harus memenuhi tiga prinsip utama, yaitu:

1. Keberlanjutan

kebutuhan

ekonomi dengan mengelola lingkungan dan sumber daya alam secara efektif dan efisien dengan yang berkeadilan perimbangan modal Masyarakat, Pemerintah dan dunia usaha.

2. Berkelanjutan social budaya dengan pembentukan nilai-nilai social budaya baru.

3. Berkelanjutan terhadap kehidupan lingkungan (ekologi) manusia untuk keselarasan antara lingkungan alam dengan lingkungan buatan.

Ada sejumlah faktor yang dapat mempengaruhi partisipasi masyarakat terhadap program yang akan dijalankan. Faktor tersebut yang bersifat mendukung keberhasilan program dan ada pula yang bersifat menghambat keberhasilan sebuah program. Menurut Angell dalam Firmansyah (2009) partisipasi yang tumbuh di dalam masyarakat dipengaruhi oleh banyak faktor. Faktor-faktor tersebut diantaranya:Usia, jenis kelamis, pendidikan, pekerjaan dan enghasilan, lamanya tinggal.
Studi

terdahulu

dalam

pengembangan Gua Selomangleng fokus pada aspek sejarah (Novalia \& Alrianingrum, 2015), dan peningkatan pendapatan daerah (Dian, Mukti, Makmur, \& Adiono, 2015). Sedangkan seharusnya dalam pengembangan pariwisata perlu diungkapan persoalan lingkungan dan manusia yang menjadi titik tumpu pariwisata itu sendiri. Sosial ekonomi manusia dan lingkungan merupakan elemen penting dari pariwisata yang berkelanjutan (Hengky, 2013; Windarti, 2016). Bahkan isu-isu terkini dari pariwisata berkelanjutan menyentuh hingga ke level indigeneous people dan empowerment (Dwijayanthi, 2017; Sutawa, 2012). Oleh karena itu penelitian ini bertujuan untuk mengetahui sejauh mana pengembangan pariwisata di obyek wisata Gua Selomangleng Kota Kediri dan implikasi pengembangannya dalam perspektif berkelanjutan.Wisata Gua Selomangleng merupakan salah satu tempat wisata yang di berada di lereng Gunung Klotok Kota Kediri.

\section{METODE PENELITIAN}

Jenis penelitian yang digunakan adalah penelitian deskriptif dengan pendekatan kualitatif. Jenis penelitian ini digunakan untuk menggambarkan suatu fenomena yang ada dengan cara mendeskripsikan permasalahan yang diteliti secara mendalam dengan data yang diperoleh melalui wawancara dan menyampaikan data tersebut secara naratif atau dengan berbagai teks. Adapun alas an peneliti menggunakan jenis penelitian deskriptif dengan pendekatan kualitatif yaitu karena penelitian ini bertujuan untuk mendapatkan data sebenarnya dan apa

Copyright $($ C 2018, Publik : (Jurnal Ilmu Administrasi), ISSN: 2301-573X (Print), ISSN: 2581- 
adanya tentang kondisi maupun situasi yang ada pada obyek penelitian di lapangan yaitu tentang pengembangan Gua Selomangleng dalam perspektif pembangunan pariwisata berkelanjutan di kota Kediri. Peneliti juga membatasi focus penelitian tentang pengembangan Gua Selomangleng dalam perspektif pembangunan pariwisata berkelanjutan pada:

1. Pengembangan pariwisata di obyek wisata Gua Selomangleng Kota Kediri. Adapun bahasan dalam subsub ini terdiri dari: sejarah Gua Selomangleng dan Program Dalam Pengembangan Wisata Gua Selomangeng.

2. Implikasi pengembangan Gua Selomangleng dalam perspektif pembangunan pariwisata berkelanjutan yang menekankan pada 4 dimensi atau prinsip utama, antara lain: lingkungan, social, budaya, dan ekonomi.

Adapun dalam penelitian ini, lokasi yang akan dijadikan sebagai tempat penelitian adalah Gua Selomangleng yang berada di Kelurahan Pojok Kecamatan Mojoroto Kota Kediri Jawa Timur. Sedangkan situs penelitan merupakan obyek penelltian dimana peneliti dapat mencari informasi dan mengetahui keadaan yang sebenarnya guna mendapatkan data dan informasi yang valid serta akurat. Dalam penelitian ini peneliti menempatkan situs penelitian pada 2 (dua) tempat yaitu: Dinas Kebudayaan, Pariwisata, Pemuda dan Olahraga Kota Kediri; dan Tokoh Masyarakat. Teknik pengumpulan data dalam penelitian ini dengan mengunakan: wawancara, observasi, studi kepustakaan, dan dokumentasi.

\section{HASIL DAN PEMBAHASAN}

Pengembangan Pariwisata di Obyek Wisata Gua Selomangleng Kota Kediri

Gua Selomangleng adalah sebuah situs Gua peninggalan jaman kerajaan Kediri yang berada di Kelurahan Pojok Kecamatan Mojoroto, Kota Kediri. Lokasinya hanya berjarak beberapa meter dengan Musium Airlangga Kediri dan Makam Eyang Boncolono. Selomangleng berasaldari kata Selo yang berarti batu dan Mangleng yang artinya menggantung. Gua Selomangleng dipercaya menjadi tempat pertapaan Dewi Kilisuci, beliau adalah Putri dari Prabu Airlangga Raja dari Kerajaan Kahuripanatau yang lebih dikenal dengan Kerajaan Kediri. Dewi Kilisuci mempunyai nama asli Dyah Ayu Puspasari yang memiliki wajah sangat cantik dan berbudi pekerti halus. Dia sangat mencintai rakyatnya dan begitu pula rakyatnya juga sangat mencintainya. Suatu hari Mahesa suro atau biasa disebut Lembu Suro, seorang adipati dari Kerajaan tetangga datang untuk melamarnya.

Lembu Suro adalah seorang yang sakti mandraguna. Kepalanya berbentuk kerbau sedangkan badannya kebawah berbentuk Manusia. Dewi Kilisuci sangat sedih mendapat lamaran Lembu Suro. Namun apa daya, kekuatan yang dimiliki Ayahandanya tidak kuasa untuk menolak lamaran tersebut. Dewi Kilisuci membuat permintaan atau syarat kepada Lembu Suro untuk dibuatkan sumur raksasa dalam waktu 1 (Satu) hari, maka berangkatlah Lembu Suro untuk membuatnya. Sumur raksasapun akhirnya tercipta berkat kesaktian LembuSuro, namun sayang Lembu Suro jatuh kedalam sumur karena dijebak Dewi 
Kilisuci. Para prajurit Kerajaan Kadiri atas perintah Dewi Kilisuci beramairamai menutup sumur dengan bebatuan yang jumlahnya begitu banyak hingga menggunung akhirnya menjadi Gunung Kelud. Oleh sebab itu, apabila Gunung Kelud meletus, daerah Kediri selalu menjadi korban sebagai wujud kemarahan arwah Lembu Suro. Setelah kejadian itu, demi menyelematkan rakyatnya dari amukan arwah LembuSuro, Dewi Kilisuci melakukan pertapaan di sebuah Gua yang sekarang dinamakan Gua Selomangleng (sebuah bukit di kaki Gunung Klotok). Bahkan Dewi Kilisuci rela untuk tidak menikah sampai akhir hayatnya.

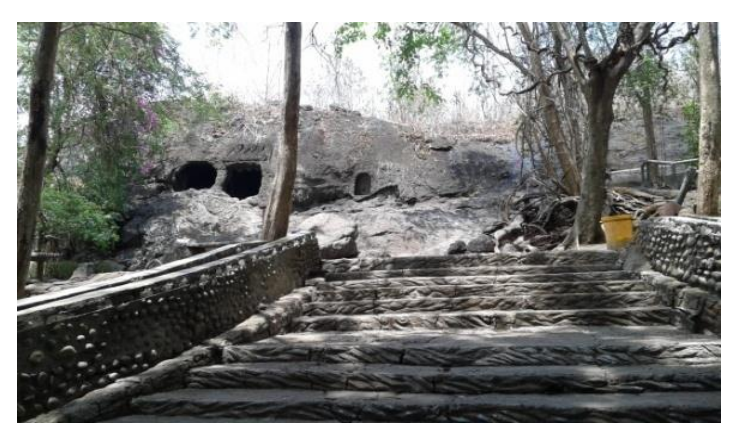

Gambar 1: Gua Selomangleng Kota Kediri

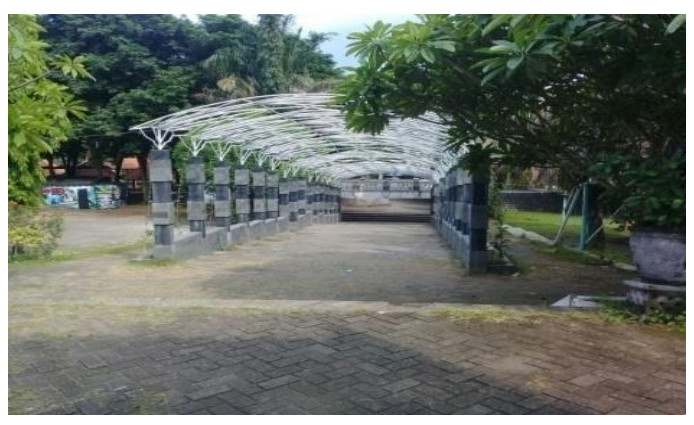

Gambar2: Taman Pergola yang baru dibangun pada tahun 2017

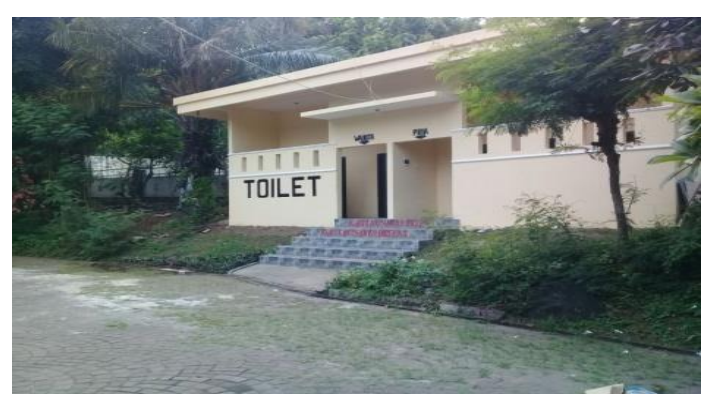

Gambar 3: Penambahan MCK (Toilet) pada tahun 2017

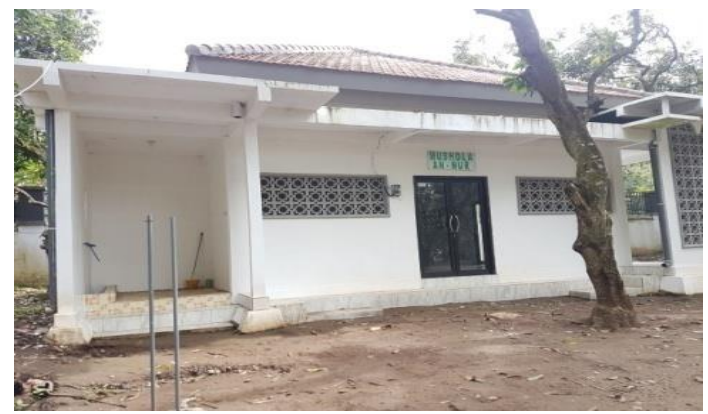

Gambar 4: Penambahan

Pembangungan Mushola Pada Tahun 2017

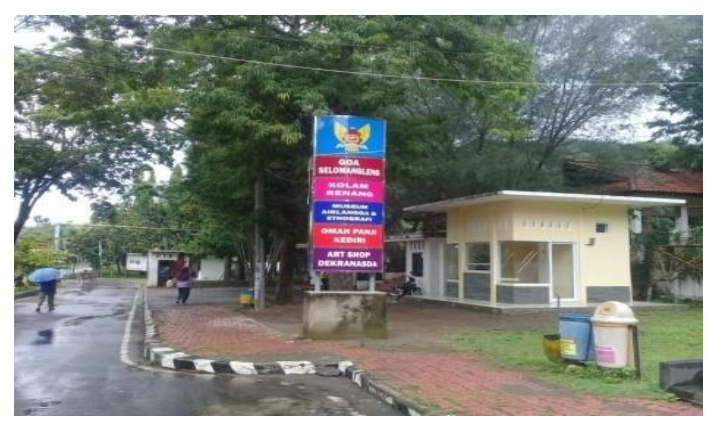

Gambar 5: Penambahan

\section{Pembangunan Ruang Pusat Informasi} Pada Tahun2017

Pembangunan dan pengembangan Gua Selomangleng di tahun 2017 telah menjadi tugas dan tanggung jawab dari Dinas Kebudayaan, Pariwisata, Kepemudaan dan Olahraga Kota Kediri. Adapun program pengembangan Gua Selomangleng seperti pada tabel 1 meliputi: 
Tabel 1: Pengembangan Gua Selomangleng Kota Kediri

\begin{tabular}{llcl}
\hline No & \multicolumn{1}{c}{ UraianPekerjaan } & TahunPengerjaan & \multicolumn{1}{c}{ Keterangan } \\
\hline 1. & Pembangunan Taman Pergola & 2017 & Baru dibangun \\
2. & Pembangunan MCK (Toilet) & 2017 & $\begin{array}{l}\text { Penambahan dari yang } \\
\text { sudah }\end{array}$ \\
& Pembangunan & 2017 & $\begin{array}{l}\text { Penambahand ari yang } \\
\text { sudah }\end{array}$ \\
3. $\quad$ Mushola/TempatIbadah & & $\begin{array}{l}\text { Penambahan dari yang } \\
\text { sudah }\end{array}$ \\
& $\begin{array}{l}\text { Pembangunan Pusat } \\
\text { 4nformasi Pariwisata }\end{array}$ & 2017 & Proses pembangunan
\end{tabular}

\section{Sumber : Olahan Data Primer (2017)}

Saat ini Pemerintah Kota Kediri mengaku masih mengurus dan menunggu surat ijin pengelolaan situs baru yang diketemukan tersebut dari pihak perhutani. Lebih lanjut Kepala Dinas Pariwisata Kota Kediri Drs. Nur Muhyar menjelaskan bahwa pihaknya telah mengajukan surat permohonan pengelolaan bersama dengan pihak Perhutani untuk penemuan situs yang berutersebut, namun sayangnya hingga saat ini belum ada balasan. Sedang menurut Drs. Nur Muhyar, langkah pertama yang akan dilakukan apabila surat ijin tersebut telah disetujui oleh pihak Perhutani adalah membuat akses jalan untuk melakukan eskalasi dengan melibatkan pihak Arkeologi yang berikutnya penemuan akan dirangkai dengan sejarah Gua Selomangleng.

Selanjutnya sikap Pemerintah Kota Kediri dalam halini Wakil Walikota Kediri Dra. Lilik Muhibbah seusai membuka festival Cakarwesi Movement mengatakan sikapPemerintah Kota Kediri menginginkan untuk pengembangan pengelolaan kawasan Gua Selomangleng terkait dengan ditemukannya beberapa benda yang memiliki nilai sejarah ini, Karena Pemerintah Kota Kediri yakin jika penemuan benda tersebut ada hubungannya dengan situs yang ada di Gua Selomangleng. Hal ini diperkuat oleh Balai Pelestarian Peniggalan Purbakala (BP3)TrowulanMojokertoJawa Timur, yang telah meninjau situs tersebut menduga bangunan yang menyerupai candi yang berada di puncak Gunung Klotok Kediri adalah peninggalan zaman Hindu-Budha yang berkembang pada abad X higga awal abad XV. Pada saat itu Balai Pelestarian Peninggalan Purbakala (BP3) Trowulan berhasil mengidentifikasi temuan sebuah struktur bata, sehingga dari singkapan tanah sisi barat dan selatan gundukan tanah tersebut, Nampak ada tatanan bata yang seperti membentuk struktur berbentuk segiempat. 
Disamping beberapa hal yang telah diungkapkan sebelumnhya, pada tahun 2016 juga telah dibangun kios-kios pedagang baru sejumlah 18 kios menghadap ketimur dan barat sebelah selatan tempat parker saat ini sudah mulai ditempati oleh para pedagang. Kemudian pengadaan tempat duduk dan pengadaan Gazebo.

Konsep pembangunan dan pengembangan sebuah objek pariwisata, tentu tidak terlepas dari empat prinsip utama yaitu lingkungan, sosial, budaya dan ekonomi. Demikian pula halnya dengan pembangunan dan pengembangan pariwisata di Gua Selomangleng Kota Kediri.

\section{A. Prinsip Lingkungan}

Pengaruh pembangunan dan pengembangan Gua Selomangleng dari segi lingkungan dapat dilihat semakin tertatanya bangunan kios pedagang yang dulunya berada dimana-mana sehingga terkesan kurang tertatarapi. Terkait dengan lingkungan, ada kepedulian dari para pedagang yang ada di Gua Selomangleng yang selalu berpartisipasi ikut membersihkan kotoran yang ada di lingkungan sekitarnya, sehingga keadaan lingkungan sekitarnya bersih, baik dan terjaga. Disamping itu ada kepedulian dari para pengunjung yang mau membuang bekas kotoran makanan maupun minuman di tempat sampah yang telah disediakan.

\section{B. Prinsip Sosial}

Pengaruh pembangunan dan pengembangan Gua Selomangleng dari segi social dapat dilihat melalui sikap masyarakat yang ada disekitarnya yang ikut mendukung perkembangan Gua Selomangleng dengan mengadakan Pawai Pembangunan dari Kelurahan
Pojok diarak menuju Gua Selomangleng, juga Pawai peringatan hari raya nyepi agama Budha yang mengara kogok-ogok dari depan Taman Sekartaji menuju Gua Selomangleng tanpa menimbulkan konflik sosiala ntar agama maupun masyarakat yang dilewati walaupun kondisi jalan menjadi macet.

\section{Prinsip Budaya}

Pengaruh pengembangan dan pembangunan Gua Selomangleng dari segi budaya dapat dilihat dengan adanya berbagai pertunjukan budaya yang ditampilkan dari kesenian rakyat yang berupa kesenian Jaranan/Kuda Lumping, Reog Ponorogo, Barongsai, Sendratari Ramayana dari agama Budha, kesenian panggung hiburan dan lainnya yang kesemuanya dapat diterima oleh segala macam lapisan masyarakat baik yang berada disekitar GuaSelomangleng maupun masyarakat lainnya.

\section{Prinsip Ekonomi}

Pengaruh pembangunan dan pengembangan Gua Selomangleng dari segi ekonomi bagi masyarakat Kelurahan Pojok Kecamatan Mojoroto Kota Kediri maupun Kelurahan lain adalah adanya peluang kerja yang makin banyak khususnya dibidang makanan dan minuman, mainan anak, penitipan sepeda, kendaraan roda dua maupun roda empat, penjualan baju yang kesemuanya ini dapat meningkatkan penghasilan dari setiap masyarakat sebagaimana yang telah penulis lakukan wawancara dengan seorang pedagang makanan bernamalbu Sri Winarni, sebagai berikut:

"saya jualan di sini kira-kira sudah ada 10 tahun tambah tahun tambah ramai pengunjungnya sehingga penghasilan saya juga meningkat.” 
Wawancara peneliti dengan penjual karcis/petugas penunggu tiket masuk yaituMbak Indra, sebagai berikut:

"Tambah tahun terus ada peningkatan jumlah pengunjung Wisata Gua Selomangleng. Tahun 2016 targetnya 102.000 realisasinya 204.647. Hal ini karena tiap tahun ada event yang ditampilkan mulai Jaranan, Musik Dangdut, Senam kesegaranjasmani bersama, kesenian tari yang ditampilkan dari generasi muda agama hindu dan sebagaiannya. Disamping itu juga ditunjang dari kegiatan promosi media elektronik."

Sebagaimana yang kita ketahui bahwa saat sekarang tiap-tiap daerah telah berlomba-lomba membenahi daerahnya dalam rangka meningkatkan pariwisatanya. Demikian juga halnya Pemerintah Kota Kediri dalam rangka meningkatkan pariwisata khususnya untuk pengembangan Gua Selomangleng telah mengadakan kerjasamadengan pihak perhutani. Kepala Dinas Pariwisata Kota Kediri Drs. Nur Muhyar mengatakan sebenarnya pihaknya telah mengajukan surat permohonan pengelolaan bersama dengan Dinas Perhutani namun sampai saat ini suratnya belum juga turun.

Terkait dengan pembangunan dan pengembangan GuaSelomangleng, Pemerintah Kota Kediri melalui Dinas Kebudayaan, Pariwisata, Pemuda dan Olah raga pada tahun 2016 telahmembangun 18 kios, rumah Panji, Gazebo, tempat MCK, dan tempat permainan anak. Sedang pada tahun 2017 telah membangun taman Pergola, MCK, Mushola, pusat informasi pariwisata dan hutan kota.
Melihat kenyataan ini sebenarnya pengembangan Gua Selomangleng masih sangat minim dengan tanah Perhutani dan tanahB rigif 16 Wira Yudha. Menurut Peneliti walaupun tanahnya sangat minim sebenarnya tempat Pariwisata bisa dikembangkan dengan membangun tempatwisata yang bersifat buatan. Maka dalam hal ini Pemerintah Kota Kediri melalui Dinas Kebudayaan, Pariwisata, Pemuda dan Olah raga perlu memikirkan pengembangan pariwisata yang bersifat buatan dan pada hari libur perlu mencoba kendaraan yang menuju kepariwisata Gua Selomangleng diparkir di tanah kosong yang ada di utara perempatan Sukorame, sedang kebaratnya diangkut dengan menggunakan kereta kelinci atau becak atau dokar dan penumpangnya diturunkan di pertigaan SMUN 5 Kota Kediri dan diarahkan menuju jalan lingkar Maskumambang dengan catatan sekitar jalan tersebut harus dibangun home industry atau handycraft dari produk-produk unggulan Kota Kediri dan makanan tradisional khas Kota Kediri maupun Kota lain serta di pintu masuk disambut musik khas Kota Kediri.

Untuk penemuan situs baru yang berada di wilayah perkotaan perlu terus ditingkatkan kerjasamanya dan kalau sudah tercapai perlu dibuatkan jalan menuju ketempat tersebut. Hal ini sesuai dengan pendapat Varozi dalamYoeti (2008) untuk pembangunan dan pengembangan bidang Pariwisata perlu beberapa hal, yaitu:

\section{Comprehensive Approach}

Diperbolehkan adanya pendekatan yang menyeluruh di dalam menentukan kebijakan dalam hal ini antara Dinas Kebudayaan, Pariwisata, Pemuda dan 
2018

Olah raga dengan Dinas lain yaitu Dinas

Perhutani dan Brigif, juga melibatkan stakeholder dan masyarakat Kota Kediri.

\section{Integrated Approach}

Perkembangan pariwisata harus terintegrasi dimana pembangunan yang dilakukan di daerah local tidak boleh bertentangan dengan pembangunan yang berskala nasional maupun global. Dalam hal ini pembangunan dilakukan Dinas Kebudayaan, Pariwisata, Pemuda dan Olah raga tidak bertentangan.

\section{Stategic Approach}

Tujuan untuk mencapai hasil yang maksimal dalam pembangunan dan pengembangan Pariwisata diperlukan strategi yang ditetapkan berdasar visi dan misi. Hal ini juga telah sesuai dengan visi dan misi Dinas Kebudayaan, Pariwisata, Pemuda dan Olah raga Kota Kediri

\section{PENUTUP}

\section{Kesmipulan}

Berdasarkan permasalahan yang telah dikemukakan pada pendahuluan, maka peneliti menyimpulkan bahwa pengembangan dan pembangunan pariwisata GuaSelomangleng Kota Kediri masih sangat minim terkendala dengan tanah perhutani dan tanah Brigirf Wira Yudha. Namun demikian Dinas Kebudayaan, Pariwisata, Pemuda dan Olahraga Kota Kediri pada tahun 2016 telah membangun dan mengembangkan Gua Selomangleng sebanyak 18 kios, Rumah Panji, Gazebo, tempat MCK dan tempat permainan anak. Selain itu di tahun 2017 juga membangun taman Pergola, MCK, Mushola, pusat informasi pariwisata dan Hutan Kota. Sehingga pada dasarnya masih diperlukan banyak usaha keras dari berbagai pihak untuk mengembangkan dan membangun Gua
Selomangleng agar sesuai dengan

prinsip-prinsip yang berkelanjutan terutama berlandaskan manfaat lingkungan dan umat manusia.

\section{Saran}

Melihat uraian yang telah disajikan dalam penulisan penelitian ini, maka peneliti akan menyampaikan beberapa saran yang mungkin bermanfaat, sebagai berikut: Pemerintah Kota Kediri hendaknya memberikan dukungan optimal kepada Dinas Kebudayaan, Pariwisata, Pemuda dan Olahraga Kota Kediri dalam pengembangan dan pembangunan Gua Selomangleng mengingat tempat pariwisata tersebut merupakan salah satu peninggalan sejarah kuno yang ada di wilayah Kota Kediri; Melihat pengembangan wisata Gua Selomangleng menemui kendala situs baru peninggalan Kerajaan Kadiri berada di wilayah territorial $\mathrm{KPH}$ Perhutani Kota Kediri, maka sebaiknya Kepala Dinas Kebudayaan, Pariwisata, Pemuda dan Olahraga Kota Kediri segera menindaklanjuti tidak hanya menunggu permohonan surat ijin pengelolaan bersama situs baru kepada Dinas Perhutani Kota Kediri. Dinas Kebudayaan, Pariwisata, Pemuda dan Olahraga Kota Kediri perlu meningkatkan kegiatan promosi baik media cetak maupun elektronik bahkan perlu pula kerjasama dengan biro agen perjalanan pariwisata demi menarik minat wisatawan domestik maupun asing; selanjutnya diharapkan masyarakat sekitar Gua Selomangleng bisa menjaga kebersihan lingkungan sekitar dan ikut berpartisipasi dalam pengembangan dan pembangunan Gua Selomangleng Kota Kediri. 


\section{DAFTAR PUSTAKA}

Baequni, M. (2002). Integrasi Ekonomi dan Ekologi: Dari Mimpi Menjadi Aksi. Yogyakarta: Insist Press.

Dian, M., Mukti, L., Makmur, M., \& Adiono, R. (2015). Strategi Pengembangan Kawasan Barat Sungai Brantas Kota Kediri Sebagai Destinasi Pariwisata Daerah Untuk Meningkatkan Pendapatan Asli Daerah ( Studi Di Kawasan Objek Wisata Selomangleng Kota Kediri ). Jurnal Administrasi Publik, 3(11), 1797-1803.

Dwijayanthi, P. T. (2017). Indigenous People , Economic Development and Sustainable Tourism: A Comparative Analysis between Bali , Indonesia and Australia. Udayana Journal of Law and Culture, 1(1), 16-30.

Dwiningrum, S. I. A. (2011). Desentralisasi Dan Partisipasi Masyarakat Dalam Pendidikan. Yogyakarta: Pustaka Pelajar.

Firmansyah, S. (2009). Partisipasi Masyarakat Dalam Pembangunan. Retrieved from http://sacafirmansyah.wordpress.co $\mathrm{m} / 2009 / 06 / 05 /$ partisipasimasyarakat/

Hadi, S. P. (2012). Dimensi Lingkungan Perencanaan Pembangunan. Yogyakarta: Gadjah Mada University Press.

Hengky, S. (2013). Envisaged the Potential of Sustainable Sacred Tourism in Java Indonesia. International Journal of Business and Social Science, 4(12), 123-127.

Novalia, E., \& Alrianingrum, S. (2015). Perkembangan Obyek Wisata Goa
Selomangleng di Kota Kediri Tahun 1992-2007. Avatara, 3(2).

Sumaryadi, I. N. (2002). Sosiologi Pemerintahan Dari Prespektif Pelayanan, Pemberdayaan, Interaksi dan Sistem Kepemimpinan Pemerintahan Indonesia. Bogor: Ghalia Indonesia.

Sutawa, G. K. (2012). Issues on Bali Tourism Development and Community Empowerment to Support Sustainable Tourism Development. Procedia Economics and Finance, 4, 413-422. https://doi.org/10.1016/S22125671(12)00356-5

Suweda, I. W. (2011). Penataan Ruang Perkotaan Yang Berkelanjutan, Berdaya Saing Dan Berotonomi: Suatu Tinjauan Pustaka. Jurnal Ilmiah Teknik Sipil, 15(2), 113-122. Tilaar, H. A. . (2009). Kekuasaan Dan Pendudukan: Kajian Manajemen Pendidikan Nasional. Jakarta: Rineka Cipta.

Windarti, Y. (2016). Local Government Attitudes toward Sustainable Tourism Development ( Case of Bandung City , Indonesia ). International Journal of Social Science and Humanity, 6(7). https://doi.org/10.7763/IJSSH.2016. V6.709

Yoeti, O. (2008). Perencanaan dan Pengembangan Pariwisata. Jakarta: Prodaya Paramita. 
